\title{
Empathy or Antipathy? The Impact of Diversity*
}

\author{
Johanne Boisjoly ${ }^{1}$ \\ Greg J. Duncan ${ }^{2}$ \\ Michael Kremer $^{3}$ \\ Dan M. Levy ${ }^{4}$ \\ Jacque Eccles $^{5}$
}

January, 2006

\footnotetext{
* Financial support from the W.T. Grant Foundation, the John D. and Catherine MacArthur Foundation, and the NICHD Child and Family Well-Being Research Network (2 U01 HD30947-07) is gratefully acknowledged. We thank Sean McCabe, Carol Boyd and William Zeller for their contributions in the early stages of this research, Brian Madden, David Mericle, and Deanna Maida for research assistance and Patricia Gurin, Bruce Meyer, Bruce Sacerdote, Thomas Sander, Heidi Williams, seminar participants at the NBER Summer Institute, the 2003 AEA meetings, Princeton University, MDRC, Johns Hopkins University, New York University, Syracuse University and referees for helpful comments on an earlier draft.

${ }^{1}$ University of Quebec at Rimouski: johanne_boisjoly@uqar.qc.ca

2 Institute for Policy Research, Northwestern University: greg-duncan@northwestern.edu

${ }^{3}$ Department of Economics, Harvard University, The Brookings Institution, and NBER: mkremer@fas.harvard.edu

${ }^{4}$ Kennedy School of Government, Harvard University: dan_levy@ksg.harvard.edu

${ }^{5}$ Department of Psychology, University of Michigan: jeccles@isr.umich.edu
} 


\title{
Empathy or Antipathy? The Impact of Diversity
}

\begin{abstract}
Mixing across racial and ethnic lines could potentially either spur understanding or inflame tensions between groups. We find that white students at a large state university who were randomly assigned African-American roommates in their first year are more likely to endorse affirmative action and view a diverse student body as essential for a high-quality education. They are also more likely to say they have more personal contact with and interact more comfortably with members of minority groups. Although sample sizes are too small to provide definitive evidence, these results suggest that students become more empathetic with the social groups to which their roommates belong.
\end{abstract}




\section{INTRODUCTION}

While the enormous costs of ethnic and class divisions are depressingly familiar (Easterly and Levine, 1997; Goldin and Katz, 1997; Mauro, 1995; Poterba, 1997; Alesina, Baqir, and Easterly, 1999), much less is known about the impact of various policies designed to ameliorate conflict between groups.

Different countries have followed very different policies regarding ethnicity. Some, such as France, encourage mixing and assimilation. Others, like Belgium, with its separate French and Flemish higher education systems, seek to preserve the cultural identity of different communities. Much of the recent U.S. emphasis on diversity in schools and workplaces is motivated by the view that mixing between members of different groups will break down stereotypes and encourage development of deeper understanding, and with it, more empathetic attitudes toward other groups (Pettigrew and Tropp, 2000). On the other hand, others argue that deliberate efforts to encourage mixing may actually inflame tensions and exacerbate conflict (Stephan, 1978).

Within this larger debate, views on the impact of affirmative action policies on relations between racial and ethnic groups differ dramatically (see Crobsy, 2004; Konrad and Linnehan, 1999; Kravitz et al. 1997 for general reviews). Gurin (2002) and Gurin et al. (2004) argue that diversity promotes critical thinking and learning among white students, while Thernstrom and Thernstrom (1997) and McWhorter (2002) argue that policies that admit minority students with lower test scores reinforce stereotypes and ultimately hurt minorities.

Much of the evidence on these issues comes from examining empirical associations between individuals' contact with members of other groups and their attitudes toward those groups (summarized in Pettigrew and Tropp, 2000; see also Belliveau, 1996; Bowen and Bok, 1999; Gurin et al., 1999; Khmelkov and Hallinan, 1999; Lopez, Gurin, and Nagda, 1998; Pettigrew, 1997; Pratkanis and Turner, 1999; and Taylor, 1995). However, a major problem with this literature is that 
those who are more tolerant of other groups are likely to choose to associate more with members of those groups, thus making it difficult to determine the direction of causality.

An alternative approach relies on laboratory studies, where assignment to treatment is randomized, thus ruling out the possibility of reverse causality. One way to interpret evidence from a fascinating set of laboratory experiments (Aronson, 1975; Aronson et al., 1978; Aronson and Patnoe, 1997; Johnson and Johnson, 1983; DeVries and Slavin, 1978; Cook, 1990; Slavin and Cooper, 1999) is that interactions with members of other groups in situations of competition can exacerbate conflict, while interactions in situations designed to reward cooperation can improve relations among groups. Another line of laboratory-based studies examines the possible stigma (of both co-workers and the individuals themselves) associated with individuals hired under race or gender-based policies (Evans, 2003; Heilman et al., 1998; Matheson et al., 2000; Resendez, 2002). A general conclusion is that stigmatization can indeed arise, but is reduced or eliminated if meritbased criteria are clearly used in the hiring decision. One limitation is that laboratory studies are typically short-term. Moreover, the extent to which laboratory conditions resemble real-world situations is unclear.

This paper investigates the consequences of intergroup interactions in one particular realworld context by examining whether attitudes and behaviors change when people of different races are randomly assigned to live together at the start of their first year of college. We choose this environment both because some students are assigned roommates randomly, thus allowing us to identify causal effects (as in Sacerdote, 2001; Zimmerman, 2003; Foster, 2003; Stinebrickner and Stinebrickner, 2000; Siegfried and Gleason, 2003; and Kremer and Levy, 2003), and because this context is relevant for policy, in particular the controversy over affirmative action.

The key Supreme Court decisions on affirmative action, Regents of the University of California vs. Bakke and the more recent Grutter vs. Bollinger, held that racial preferences in 
admission were not permissible as a way to rectify current or previous discrimination against minorities, but nonetheless upheld affirmative action programs based on the value of diversity to

education. As argued above, existing evidence on the causal effect of association with members of other groups on attitudes is not definitive. The university we examine has a strong affirmative action policy, and on average, African-American students at the university have test scores more than one standard deviation below those of their white counterparts. If affirmative action indeed reinforces stereotypes among white students, as Thernstrom and Thernstrom (1997) suggest, this context seems as likely a place as any to see the effect.

We find that white students who are randomly assigned African-American roommates are significantly more likely to endorse affirmative action and have personal contact with members of other ethnic groups after their first year. Overall, the results suggest that mixing with members of other groups tends to make individuals more empathetic to these groups. We find no evidence for the Thernstrom and Thernstrom effect. However, a key limitation to bear in mind is that our sample size is small, so the results should be interpreted as suggestive rather than definitive. Due to the nature of our data and our small sample size, we cannot assess the impact of affirmative action on minorities.

This paper proceeds as follows: Section II describes the data and measures used in our analysis; Section III details our results; and a summary and discussion appear in Section IV.

\section{ROOMMATE ASSIGNMENT, DATA SOURCES, OUTCOME MEASURES, AND DESCRIPTIVE STATISTICS}

We examine students who were randomly assigned roommates at an academically strong state university. Our data are on students who entered in the fall of each year between 1997 and 2000. Most students initially live in university residence halls, but they usually move out of residence 
halls after their first year. Only about 17 percent of students live with their initial randomly assigned roommate after the first year. ${ }^{6}$

\section{II.A. Roommate Assignment}

Since our identification strategy is based on taking advantage of randomness in roommate assignment, it is worth reviewing the roommate assignment process in some detail. In the spring before entering university, incoming students submit (by mail) housing applications listing basic housing preferences (smoking/non-smoking room, substance-free housing, single/double/triple occupancy, geographic area of campus, and gender composition of corridor), as well as any requests to live in an enrichment residence hall or to be assigned a specific roommate. For some of these preferences, students could list a first, second, and third choice. Those students who did not elect to live in an enrichment residence hall or select a specific roommate were randomly assigned to their rooms by a computer unless they missed the lottery deadline (usually around the end of April).

Our analysis focuses exclusively on those students who were randomly assigned rooms and roommates as part of the lottery process. These students were randomly assigned rooms and roommates conditional on gender, cohort, and the combination of housing preferences. Hence these roommate assignments should be random within cells defined by the combination of gender, cohort, and first, second, and third choices of basic housing preferences. All of our analyses control for the student's combination of first choices of housing preferences, which amounts to fixed-effects regressions in which the unit of observation is the cell (i.e. combination of values of housing variables plus gender and cohort). Standard errors are considerably higher in fixed-effects models

\footnotetext{
${ }^{6}$ This is based on our survey, detailed below, which was administered in the winter of 2002 to a sample of students who entered the university in 1998-2000 and who were randomly assigned to their first-year roommate.
} 
that control for second and third choices, but key coefficient point estimates, and therefore our conclusions, are largely unaffected by these extensions.

To verify that the housing assignment process was indeed random within cells, we first spoke with housing officers to understand how the assignment process worked and reviewed the documentation of the computer software used to make room assignments. Then, using techniques discussed more fully in Kremer and Levy (2003), we verified that, controlling for all housing preference choices, initial roommates’ background characteristics were not significantly correlated. For students in the entering 1998-2000 cohorts, regressions of entering student characteristics on those of their roommates, controlling for the first choice of housing characteristics, yielded only 6 significant coefficients (3 positive and 3 negative) out of 140 variables checked. Only 3 of 140 correlations were in the 5 percent tail of a simulated distribution of correlations under random assignment. As Kremer and Levy (2003) discuss, these checks for random assignment have reasonable power. It therefore seems reasonable to assume that controlling for first choices produces a sample that is close enough to random that residual departures from random assignment in the second and third preferences are unlikely to impart serious bias.

We use the term "roommate" to refer to the roommate(s) initially assigned to the student in the housing lottery. ${ }^{7}$ Ours are thus intention-to-treat estimates. Instrumenting for the actual firstyear roommate with the initially assigned roommate would, however, give similar results, since less than 5 percent of students switch roommates during their first year. University policy does not allow roommate changes during the first six weeks of classes except for extreme cases such as those involving violence, and it strongly discourages any roommate changes during the first year.

\footnotetext{
${ }^{7}$ If we used actual roommate (instead of the initially assigned roommate) in our regressions, our peer-effect estimates could be biased by self-selection among roommates.
} 


\section{II.B. Data Sources}

We draw our data from several sources. The university’s housing office provided data on each student's housing application and housing occupancy. Racial/ethnic, socioeconomic and attitudinal data on students were gathered from the Cooperative Institutional Research Program's (CIRP) Entering Student Survey, an annual survey of the American higher-education system conducted jointly by the American Council on Education and the University of California, Los Angeles. Entering students at the university in our study fill in this survey at an orientation session before classes begin. The large majority of students filled out this survey at a special summer orientation session, before meeting their roommates, although a few may have met their roommates first.

The CIRP includes questions on socioeconomic background (parental education and income), positive and problem behavior (e.g., extracurricular activities during the last year of high school, drinking, smoking, etc.), attitudes toward a wide range of social policies (including affirmative action), goals students have set for themselves, and activities students plan to conduct in the future. Race and ethnicity were asked in the single question: “Are you (mark all that apply): White/Caucasian, African American/Black, American Indian, Asian American/Asian, Mexican American/Chicano, Puerto Rican, Other Latino, Other.” We coded as “white” respondents who marked only the first category, "black” respondents who marked only the second category and “Asian” respondents who marked only the fourth category. For our "Hispanic” designation we included respondents who gave "Mexican American/Chicano,” “Puerto Rican,” or “Other Latino” and gave no other response. All respondents marking more than one category, marking “American Indian,” or marking “Other” fall into our “other” category. ${ }^{8}$

\footnotetext{
${ }^{8}$ Some 94 percent of students choosing “African American/Black” gave it as their only response.
} 
CIRP measures used as control variables in our regressions include both self and average roommate responses to questions about: i) years of father's education; ii) years of mother's education; iii) high school grade point average; and iv) family income collapsed to the intervals of $<\$ 50,000$, $\$ 50,000$ - $\$ 74,999, \$ 75,000$ - $\$ 149,999$ (used as the reference category), $\$ 150,000$ $\$ 199,999$, and $\$ 200,000$ or more. We use CIRP data on affirmative action and other attitudes as baseline controls in our estimates of the effects of roommate assignment on subsequently measured attitudes.

We also controlled for respondents' and roommates’ high school test scores. Since some students took only the SAT, others took only the ACT, and some took both, a common admissions test score measure was needed as an academic background variable. We therefore standardized test scores using the ACT scale based on concordance tables published by both ACT, Inc. and the College Board.

Outcome measures are drawn from a survey we administered to students who entered the university in the Fall of 1997-2000 and were randomly assigned roommates. The survey was administered via the internet with a telephone follow-up to maximize response rates. The timing of our research grants dictated that we administer our survey in two waves. An initial internet survey with very limited telephone follow-up was conducted in the winter/spring of 2002. It focused on the 1998, 1999, and 2000 cohorts, who, at the time of the survey, were more than halfway through their second, third and fourth years, respectively. Since members of the 1997 entering cohort who graduated in four years had already left the university, we initially succeeded in securing interviews from only 8.5 percent of them.

We later obtained funding to launch a more intensive effort to locate and interview the 1997 cohort by internet, mail, and telephone, beginning in the summer and early fall of 2003. As detailed below, these efforts were quite successful and produced a high response rate. 
Of all entering students in the 1997-1999 cohorts, 89-90 percent completed the CIRP survey (see Table 1; response rates for the 2000 cohort are not available). Of the 14,235 CIRP respondents, 3,246 opted to live in enrichment residence halls, 2,354 requested a roommate, 980 requested to live alone during their first year, 5,583 failed to meet the lottery deadline, and 63 otherwise-eligible students were not assigned a roommate, leaving 2,010 students eligible for our lottery sample. Some 1,647 of these students designated themselves as "white.” The follow-up survey response rate among this sample was 78 percent and produced an analysis sample of 1,278. Missing data on individual survey items reduced this case count further. We address the issue of possible nonresponse bias below.

Outcome measures were derived from sections in the follow-up survey corresponding to three broad domains: attitudes, behaviors, and goals. Questions on racial attitudes in the survey ask for strong agreement (coded as 4), agreement (3), disagreement (2), or strong disagreement (1) with the following statements: i) “Affirmative action in college admission should be abolished,” ii) “Affirmative action is justified if it ensures a diverse student body on college campuses,” and iii) "Having a diverse student body is essential for high quality education."9 The first of these items was also asked with identical wording on the 1997, 1999 and 2000 entering-student CIRP survey. Neither the second nor third items were asked in any of the CIRP surveys.

On the behavior front, respondents to our follow-up survey were also asked to specify the number of times per month when "I have personal contact with people from other racial/ethnic groups,” when "I interact comfortably with people from other racial/ethnic groups,” and when "I socialize with someone with an African-American background.”

\footnotetext{
${ }^{9}$ We explored with factor analysis whether these or any other attitudinal items could be combined into an index, but in no case were the correlations among three items high enough to warrant this.
} 
The section on goals in both the CIRP and the follow-up survey contained questions about major life goals such as "Becoming an authority in my field” and "Being very well off financially." In terms of goals related to race, respondents were asked how imperative the following goals were to them personally: "help promote racial understanding," "helping others who are in difficulty," “working to eliminate discrimination against people of color," and "participating actively in civil rights organizations.” All goals were rated on a scale of essential (coded as 4), very important (3), important (2), and not important (1).

Given the ordinal nature of the key attitudinal outcomes, we used ordered probit regression. Results from comparable OLS models, which presume a cardinal scale for the attitudinal responses but also increase the precision of the estimates, are shown in our tables for purposes of comparison. In all cases, responses were scaled so the higher scores indicated more "liberal” attitudes and behaviors. Since a number of these and related questions were included in the entering-student CIRP survey, we include baseline controls for the respondent's own responses (standardized and scaled in a "liberal" direction) to the following statements: i) "Affirmative action in college admissions should be abolished;" ii) "Race discrimination is no longer a major problem in America”; and iii) “Colleges should prohibit racist/sexist speech on campus.” To control for classrelated attitudes, we also control for responses to the CIRP question "Wealthy people should pay a larger share of taxes than they do now.”

\section{II.C. Descriptive statistics}

Table 2 shows descriptive statistics for entering students, and Appendix Table 1 shows comparable data for roommates as well as follow-up survey-based measures. The affluent nature of the sample is reflected in the high average levels of paternal (16.4 years) and maternal (15.8 years) education and the very small fraction of students coming from families with annual incomes under 
$\$ 50,000$ (columns 1 and 2 of Table 2). Test scores and high school grade-point averages are high. Most entering students agree that racial discrimination is still a problem but students have disparate opinions about whether affirmative action policies should be abolished. Attitudes toward redistributive taxation fall in the middle of the 1-4 scale. Cross-racial/ethnic contact and comfort levels are quite high.

Of the 1,278 white respondents, 35 were assigned at least one black roommate, 98 were assigned at least one Asian roommate, 40 were assigned at least one Hispanic roommate, and 69 were assigned at least one "other race” roommate. The rest were assigned white roommates. The small number of whites assigned black roommates suggests that our analysis might best be treated as a pilot study rather than a definitive analysis. Despite the limits on the precision of our estimates of roommate impacts on white students, many of the estimated effects are statistically significant at conventional levels.

Differences between students who met the lottery deadline and did not request roommates and the rest of the students in the university should not bias our estimates of peer effects within the lottery sample but could potentially affect the generalizability of our results to the larger university population. However, despite the considerable statistical power, a comparison of white follow-up survey respondents with the much larger sample of white students who failed to meet the lottery criteria reveals few statistically significant differences on academic background, parental education, and racial attitudes (columns 3 and 4 of Table 2) and on broader outcomes such as frequency of socializing or partying in high school, and perceived likelihood of joining a fraternity or sorority (results not shown). White students in the lottery sample did have a slightly but statistically significantly higher high school GPA (3.78 vs. 3.75) and were less likely to come from very highincome families (11.9 percent vs. 16.7 percent) than white students not in the lottery sample. 
There are no significant differences in the response rates of whites assigned white roommates and those assigned black roommates after controlling for housing request cells.

Columns 5 and 6 of Table 2 show differences in initial characteristics between white respondents and non-respondents to the follow-up survey. Respondents come from significantly lower-income families and have somewhat higher test scores and high school grades. While there are no significant differences in response rates in terms of roommate income levels, survey response rates were significantly lower (67.5 percent vs. 78.6 percent) among the whites assigned roommates with missing data on CIRP-reported family income than among whites with roommates who reported family incomes on the CIRP. We explore possible non-response bias below.

The seventh and eighth columns show summary statistics for all blacks in the randomassignment roommate pool, and the significance level of differences between white and black students. There are no significant socioeconomic differences between white respondents to the follow-up survey and all black students in the random-assignment roommate pool (columns 2 and 7). However, test scores and high school grade-point averages for whites exceed those for blacks by more than a standard deviation of the distribution within the university. While blacks in our sample are at the $82^{\text {nd }}$ percentile of all ACT test takers nationally, whites are at the $93^{\text {rd }}$ percentile. ${ }^{10}$ Blacks in our sample are almost two standard deviations more likely than whites to endorse affirmative action.

In general, there are not large differences in observables between blacks in the lottery sample and other black students (columns 9 and 10), although blacks in the lottery sample do have higher family income. Black students in the lottery sample could also differ from other black students in unobservable ways, and in particular blacks who were particularly averse to having

\footnotetext{
${ }^{10}$ These are scores from high school graduates in 2000-2002 as reported on http://www.act.org/aap/scores/norms1.html
} 
white roommates may be more likely to avoid the lottery by requesting a particular roommate. However, only 40 percent of black students who were not in the lottery sample lived with a black roommate in their first year of college, so it does not seem that blacks in the lottery sample were uniquely willing to live with white roommates. Many of those who were not in our lottery sample presumably simply missed the lottery deadline.

There is little evidence that blacks outside the lottery sample had particularly strong views on racial questions. There were no significant differences between blacks in the lottery sample and outside it on CIRP questions asking whether race discrimination is a problem, whether colleges should prohibit racist/sexist speech, or the importance of promoting racial understanding. Blacks outside the lottery sample were actually slightly less opposed to abolishing affirmative action than those in the lottery sample. While we do not estimate the impact on white attitudes of being assigned a random roommate from the black undergraduate population, we accurately measure the impact on white attitudes of being assigned a roommate from the population of blacks willing to enter the lottery system. This group does not seem to be particularly anomalous, and examining this population may be most relevant for real-world policies that affect racial mixing, such as contracting or expanding on-campus housing or introducing on-line systems that allow students to choose their own roommates.

\section{RESULTS}

We begin our discussion of results with a bivariate contrast that previews our regressionbased findings. Figure 1 shows the distribution of responses to the question "Affirmative action in college admissions should be abolished” for white respondents who were randomly assigned black and white roommates. A test for differences in these distributions is not very powerful given the small sample size and yields a p-value of 0.35. The regression analysis reported below controls for 
respondents' attitudes prior to meeting their roommates, which greatly sharpens the precision of our estimates. It also uses fixed-effect controls for housing preferences to eliminate the possibility of bias from correlations between attitudes and housing preferences.

\section{III.A. Regression results}

Table 3 presents results from three regression specifications for three different attitudinal outcomes. Each column in this table constitutes a separate regression in which the given dependent variable is regressed on the set of respondent and roommate measures listed in the rows and notes of the table. All are fixed-effects regressions in which the unit of observation is the cell (i.e. combination of values of housing variables plus gender and cohort). Huber-White methods adjust standard errors for heteroskedasticity and for the clustered nature of our roommate data.

The first, fourth, and seventh columns show coefficients on assignment to a black rather than white roommate from ordered probit regression in which the four-point response to these three measures are taken as dependent variables and the only other controls are for housing preference fixed effects. In all three cases the coefficients are statistically significant at the .05 level or less. ${ }^{11}$ The second, fifth, and eight columns display results from ordered probit regressions with a full set of controls, whereas the third, sixth, and ninth columns display results from OLS regressions (also with a full set of controls) to check for robustness.

Being assigned a black roommate was associated with more positive attitudes toward affirmative action and diversity policies. Despite the relatively small sample, all but one of these effects were statistically significant at the 5 percent level. Endorsement of affirmative action

\footnotetext{
${ }^{11}$ The question "Affirmative action in college admissions should be abolished" was asked in identical form in the freshman CIRP and in our own follow-up survey. One concern is that our results are driven by large changes in just one or two white respondents assigned black roommates. In fact, fewer than one-third of these whites gave the same response category to the two surveys. For example, of the eight whites initially agreeing that affirmative action policies should be abolished, two changed their responses to "disagree" and three changed to "strongly disagree."
} 
questions was between one-third and one-half of a standard deviation higher among whites who were randomly assigned black roommates than among whites assigned white roommates. Estimated effects on endorsement of the proposition that "a diverse student body is essential for high-quality education" exceed half a standard deviation in the ordered probit regressions. The estimated effect sizes translate into increments in the four-point agree-disagree scale of one-third to three-quarters of a point. Responses to these attitudinal questions for white students assigned other minority roommates did not differ significantly from white students assigned white roommates. ${ }^{12}$

Not surprisingly, the respondents’ own prior responses to affirmative action and income redistribution questions in the entering-student CIRP questionnaire were strong significant predictors of affirmative action responses $1 \frac{1}{2}$ to $6 \frac{1}{2}$ years later in several cases (results available upon request). The respondent's own SAT/ACT test scores had an inconsistently negative impact on current affirmative action attitudes, while maternal schooling had an inconsistently positive association with them.

Students who were assigned black roommates during their first year report more frequent personal contact and comfortable interactions with members of other racial/ethnic groups in later years (Table 4, columns 1 and 2). But while reported contact and comfort with minorities increased, reported friendships and socializing did not change significantly (Table 4, columns 3 and 4). ${ }^{13}$ In no instance was assignment to other minority roommates a significant predictor of these four outcomes.

\footnotetext{
${ }^{12}$ When we broke the "other minority" category into "Asian”, "Hispanic” and "mixed” we found no significant differences between any of these categories and the omitted, white roommate, category.

${ }^{13}$ While we were able to control for baseline measures of the outcome in the regressions where the dependent variable was an attitude, we were not able to do so in the regressions where the dependent variable was a behavior (because we lacked baseline data on behaviors). Other things being equal, this makes it harder to detect a statistically significant roommate effect in the behavior regressions than in the attitudinal ones.
} 
The follow-up survey also asked respondents how long they had lived with their roommates, how often they socialized with their initial roommates both during the first year and in the twelve months prior to the follow-up survey, and how friendly they still were with their initial roommates. Since these questions were not asked for each specific randomly-assigned roommate, we restricted the sample of white students from the 1,278 who responded to the follow-up survey to the 1,087 white students who had only one roommate. The vast majority (923, or 85 percent) had white roommates; 21 had black roommates, 70 had Asian roommates, 25 had Hispanic roommates and 48 had "other" race roommates. We found no statistically significant differences in frequency of subsequent interactions depending on roommate race. For example, 14 percent of whites with white roommates and 15 percent of whites with black roommates considered these roommates to be their "best college friend." Very close fractions (41 percent and 45 percent, respectively) were either "not in touch" or "did not get along” with these roommates. Similar fractions (14 percent and 10 percent) had socialized more than once a week with their first-year roommates in the past year, while 62 percent and 50 percent had socialized more than once a week with their initial roommates during their first year. Keeping in mind the low power for this analysis, there did not appear to be appreciable differences in the duration or nature of friendships white students struck with white and black roommates.

\section{III.B. Extensions}

We explored several extensions of the above analysis: First, we investigated whether the effects of being assigned a black roommate persisted over time. Second, we explored whether our earlier findings on affirmative action attitudes could result merely from whites having been assigned roommates with more positive affirmative action attitudes. Finally, we explored whether having a 
black roommate affected race-related goals such as "helping to promote racial understanding” and "helping others who are in difficulty."

We estimated a number of models that allowed for the impacts of being assigned a black roommate to differ by cohort. Since the impact of initial roommate assignment could fade over time, or change when one leaves the university, we examined a specification allowing for a linear interaction between cohort and roommate assignment, as well as a specification interacting roommate assignment with a dummy for the 1997 cohort. ${ }^{14}$ The sample sizes are too small to draw strong conclusions from interaction terms, but point estimates suggest at least some roommate effects fade once students leave the university. ${ }^{15}$ The interaction term on the reverse-scaled "affirmative action in college admissions should be abolished" item suggests virtually no attitude difference for 1997 cohort members assigned black vs. white roommates. There is also some evidence of 1997 cohort differences for the second affirmative action item, although the t-statistic on the interaction term is less than one.

Given the much stronger endorsement of affirmative action policies among black than white first-year students, it is theoretically possible that the apparent race-of-roommate effect on whites' endorsement of affirmative action policies in the follow-up survey results from merely having been assigned roommates with more positive affirmative action attitudes. We tested for this by including in the regressions listed in Table 3 measures of initially-assigned roommates' CIRP-based attitudes on affirmative action. The key coefficients on roommates' race increased slightly in absolute value

\footnotetext{
${ }^{14}$ The rationale for the interaction models is that most students in the 1997 cohort responded to our follow-up survey after they had graduated, so we may expect the effects for this cohort to be different from the effects for other cohorts.

${ }^{15}$ This result is in contrast with work from Gurin (1999) that suggests that diversity experiences during college had effects on the extent to which graduates were "living racially and ethnically integrated lives in the post-college world."
} 
and remained statistically significant, providing no evidence that initial roommates' attitudes account for the race-of-roommate effect.

Finally, we found no effect of having a black roommate on goals. Having a black roommate had no substantial association with endorsement of the imperatives to "help promote racial understanding," "helping others who are in difficulty," “working to eliminate discrimination against people of color,” and "participating actively in civil rights organizations.”

\section{III.C. Robustness checks}

Although roommates were randomly assigned on the basis of their first, second and third choice of housing characteristics, our analysis included fixed-effect controls only for their first choices. We also estimated OLS models with fixed-effect controls for all possible combinations of first and second choices and with all possible combinations of first, second and third choices. This reduces power because there are many possible combinations of first, second and third choices of housing characteristics. Key coefficients increased somewhat, but standard errors increased markedly, particularly in the case of controls for categories representing combinations of all three sets of preferences.

Although the power was not very high, we estimated separate models for male and female respondents and failed to find significant gender differences in the coefficients on the key roommate characteristic variables in Table 3.

The SES differences between white respondents and non-respondents to our follow-up survey lead us to attempt to adjust for possible non-response bias. We did this in two ways and in neither case found evidence that non-response bias might explain our results. First, we estimated a Heckman two-step model in which the first stage model predicted response status among the 1,647 white students eligible for the survey, and the second stage estimated a version of the regressions 
listed in Table 3 that adjusted for predicted non-response using Mills Ratio methods. Since it proved impossible to estimate the model with fixed effects based on all possible combinations of first rooming preferences, we instead estimated a model that included the preference variables as a set of additive dummy variables. In no case did the key coefficients on having black roommates change by more than .02 . The coefficient on having a roommate from a high-income background fell by .01 .

Our second approach to non-response bias was to develop a set of non-response weights and then re-estimate the OLS regressions in Tables 3 and 4 using those weights. To locate sample subgroups that differed maximally in terms of response rates, we used a very flexible search

algorithm. ${ }^{16}$ Response rates range from 68 percent for high-income whites to 85 percent for the nothighest-income respondents of the 1997 from high SES background. We used the inverse of the response rates for the subgroups to weight the OLS regression results in Tables 3 and 4 . None of the key coefficients changed by more than .03.

\section{SUMMARY AND DISCUSSION}

We find that white students randomly assigned African-American roommates express more positive attitudes toward affirmative action and interacted more comfortably with minorities several years after college entry than white students assigned white roommates. One interpretation of our results is that students become more sympathetic to social policies directly related to the social groups to which their roommates belong, with supportive racial attitudes toward affirmative action being most closely associated with roommates' race. These findings are consistent with the evidence from social psychology that having close personal interactions with people from different

16 Specifically, we used the CHAID option in SPSS's ANSWER TREE. Details are available from the authors upon request. 
groups leads to a greater understanding of, and empathy with, such people (Pettigrew and Tropp, 2000). Consistent with such a view, in related work (Boisjoly et al. 2003) we find that whites become less supportive of redistributive policies when they are assigned roommates from wealthy families.

Although African Americans have lower high school grades and standardized test scores in the university we study, we found no evidence to support the claim of some opponents of affirmative action that accepting more minority applicants than would be admitted under a purely test score-based process reinforces racial stereotypes and ultimately hurts minorities.

The pattern of our results seems to indicate that roommates tend to affect attitudes (such as endorsement of affirmative action policies or being in favor of more diversity) and intermediate behaviors (such as having personal contact or being comfortable interacting with blacks), but have little or no effect on harder-to-change behavior (such as befriending or socializing someone from another racial/ethnic group) and long-term goals (such as assigning greater importance to the imperative "helping to promote racial understanding”).

An important limitation of our study is the small numbers of whites assigned to black roommates. While standard errors reflect the small sample sizes, our study can be seen in some ways as a pilot study, and its conclusions should be viewed as suggestive rather than definitive. Moreover, we can examine only the effect on individuals of being randomly assigned a roommatewe cannot identify the general equilibrium effects of affirmative action, and we cannot determine if affirmative action leads to general changes in white attitudes other than those caused by increased exposure to African Americans. For example, we cannot rule out the possibility that the decision to adopt affirmative action policies at a university reinforces stereotypes among students who read about the policy in a newspaper. 
One topic for future research is to better understand the channels through which exposure to other groups affects attitudes. A variety of channels are plausible, from changes in preferences to Bayesian learning. People may simply become more empathetic to those with whom they spend more time, as argued by Mulligan (1997). Alternatively, one could tell a purely informational story in which whites who believe discrimination is a thing of the past learn otherwise if they are assigned an African-American roommate. Understanding the particular channels will be important for assessing whether working, studying, or sharing a neighborhood with African Americans is likely to have similar effects as being assigned an African-American roommate. 


\section{References}

Alesina, A., R. Baqir, and W. Easterly. 1999. "Public goods and ethnic divisions.” Quarterly Journal of Economics, 114: 1243-84.

Aronson, E. 1975. "The Jigsaw Route to Learning and Liking." Psychology Today, February.

Aronson, E., D.L. Bridgeman, and R. Geffner. 1978. "The Effects of a Cooperative Classroom Structure on Students' Behavior and Attitudes." In Social Psychology of Education: Theory and Research, edited by D. Bar Tal and L. Saxe. New York: Halstead Press.

Aronson, E. and Patnoe. S. 1997. The Jigsaw Classroom. New York: Longman.

Belliveau, M. A. 1996. The Paradoxical Influence of Policy Exposure Affirmative Action Attitudes. Journal of Social Issues, 52(4), 99-104.

Boisjoly, J., G. Duncan, M. Kremer, D. Levy, and J. Eccles. February 2003 “Empathy or Antipathy? The Consequences of Racially and Socially Diverse Peers on Attitudes and Behaviors.” Joint Center for Policy Research. Working paper no. 326.

Bowen, W. and R. Bok. 1999. Shape Of The River: Long-Term Consequences Of Considering Race In College And University Admissions. Princeton: Princeton University Press.

Cook, S.W. 1990. "Toward a Psychology of Improving Justice." Journal of Social Issues, 46: 147-61.

Crosby, F. J. 2004. Affirmative Action is Dead; Long Live Affirmative Action. New Haven, CT: Yale University Press.

DeVries, D.L., and R.E. Slavin. 1978. "Teams-Games-Tournaments (TGT): Review of Ten Classroom Experiments." Journal of Research and Development in Education, 12: 28-38.

Easterly, W. and R. Levine. 1997. Africa’s Growth Tragedy: Policies and Ethnic Divisions. Quarterly Journal of Economics, 112(4): 1203-50.

Evans, D. C. 2003. A Comparison of the Other-Directed Stigmatization Produced by Legal and Illegal Forms of Affirmative Action. Journal of Applied Psychology, 88(1), 121-130.

Foster, J. 2003. "Peerless Performers: The Absence of Robust Peer Effects at a Large, Heterogeneous University.” Unpublished Manuscript, The University of Maryland.

Goldin, C. and L. Katz. 1997. Why the United States led in education: Lessons from secondary school expansion, 1910 to 1940. NBER Working Paper No. 6144.

Gurin, P. 2002. “Expert Report Of Patricia Gurin” for Gratz, et al. v. Bollinger, et al., No. 9775321(E.D. Mich.) and Grutter, et al. v. Bollinger, et al., No. 97-75928 (E.D. Mich.), obtained on December 8, 2002 from http://www.umich.edu/ urel/admissions/legal/expert/gurintoc.html

Gurin, P., B. Nagda, and G. Lopez. 2004. The Benefits of Diversity in Education for Democratic Citizenship. Journal of Social Issues, 60(1): 17-34.

Gurin, P. 1999. "New Research on the Benefits of Diversity in College and Beyond: An Empirical Analysis," Diversity Digest, Spring, 1999, (Washington, DC: Association of American Colleges and Universities, 1999): 5/15. 
Gurin, P., T. Peng, G. Lopez, and B. Nagda. 1999. Context, identity, and intergroup relations. In D. A. Prentice and D. T. Miller (Eds.), Cultural divides: Understanding and overcoming group conflict (pp. 133-172). New York: Russell Sage Foundation.

Heilman, M. E., W. S. Battle, C. E. Keller and R. A. Less. 1998. Types of Affirmative Action Policy: A Determinationa of Reactions to Sex-Based Preferential Selection? Journal of Applied Psychology. 83, 190-205.

Johnson, D.W., and R.T. Johnson. 1983. "The Socialization and Achievement Crisis: Are Cooperative Learning Experiences the Solution?" Applied Social Psychology Annual, Vol. 4, ed. L. Bickman. Beverly Hills, CA: Sage.

Konrad, A. M. and F. Linnehan. 1999. Affirmative Action: History, Effects and Attitudes. In G. N. Powell (ed.). Handbook of Gender and Work (pp.429-452). Thousand Oaks, CA: Sage.

Khmelkow, V. T., and M. T. Hallinan. 1999. Organizational effects on race relations in schools. Journal of Social Issues, 55 (4): 627-646.

Kravitz, D. A., D. A. Harrison, M. E. Turner, E. L. Levine, W. Chaves, E. T. Brannick et al. 1997. Affirmative Action: A Review of Psychological and Behavioral Research. Bowling Green, OH: Society for Industrial and Organizational Psychology.

Kremer, Michael and Levy, D. 2003. Peer Effects and Alcohol Use Among College Students." NBER working paper 9876, July.

Lopez, G. E., P. Gurin, and B. A. Nagda. 1998. Education and understanding structural causes for group inequalities. Political Psychology, 19: 305-329.

Matheson, K. J., K. L Warren, M. D. Foster and C. Painter. 2000. Reactions to Affirmative Action: Seeking the Bases for Resistance. Journal of Applied Social Psychology. 30, 1013-1038.

Mauro, P. 1995. Corruption and Growth. Quarterly Journal of Economics, 110: 681-712.

McWhorter, J. 2002. “The Campus Diversity Fraud.” City Journal, 12(1) : 74-81.

Mulligan, C. B. 1997. Parental priorities and economic inequality. Chicago : University of Chicago Press.

Pettigrew, T. F. 1997. Generalized intergroup contact effects of prejudice. Personality and Social Psychology Bulletin, 23: 173-185.

Pettigrew, T. F. and L. R. Tropp. 2000. Does Intergroup Contact Reduce Prejudice: Recent Meta-analytic Findings. In S. Oskamp (Ed.) Reducing Prejudice and Discrimination (pp. 93-114). Mahwah, NJ: Lawrence Erlbaum Associates.

Poterba, J.M. 1997. Demographic structure and the political economy of public education. Journal of Public Policy and Management, 16: 48-66.

Pratkanis, A. R. and M E. Turner. 1999. The significance of affirmative action for the souls of White folk: Further implications of a helping model.” Journal of Social Issues, 55 (4): 787-815.

Resendez, M. G. 2002. The Stigmatizing Effect of Affirmative Action: An Examination of Moderating Variables. Journal of Applied Social Psychology, 32, 185-206. 
Sacerdote, B. 2001. Peer effects with random assignment: Results for Dartmouth roommates. Quarterly Journal of Economics, 116.

Sherif, M. et al. 1961. Intergroup Conflict and Cooperation: The Robbers' Cave Experiment. Norman, Okla.: University of Oklahoma Institute of Intergroup Relations.

Siegfried, J. and M. Gleason. 2003. Academic Peer Effects. Working Paper. Vanderbilt University.

Slavin, R. E. and R. Cooper. 1999. Improving intergroup relations: Lessons learned from cooperative learning programs. Journal of Social Issues, 55 (4): 647-664.

Stephan, W.G. 1978. "School Desegregation: An Evaluation of Predictions Made in Brown v. Board of Education." Psychological Bulletin 85: 217-38.

Stephan, W. G. and K. Finlay 1999. The role of empathy in improving intergroup relations. Journal of Social Issues, 55 (4): 729-744.

Stinebrickner, T.R. and R. Stinebrickner. 2000. Peer Effects among Students from Disadvantaged Backgrounds. Working Paper. The University of Western Ontario.

Taylor, M. C. 1995. White Backlash to Workplace Affirmative Action: Peril or Myth? Social Forces, 73, 1385-1414.

Thernstrom, S. and Thernstrom, A. 1997. America In Black And White: One Nation, Indivisible. New York: Simon and Schuster.

Zimmerman, D. 2003."Peer Effects in Higher Education: Evidence from a Natural Experiment." Review of Economics and Statistics, 85(1): 9-23. 
Figure 1: Roommate Race and Attitudes Towards Affirmative Action

Affirmative Action In College Admissions Should Be Abolished

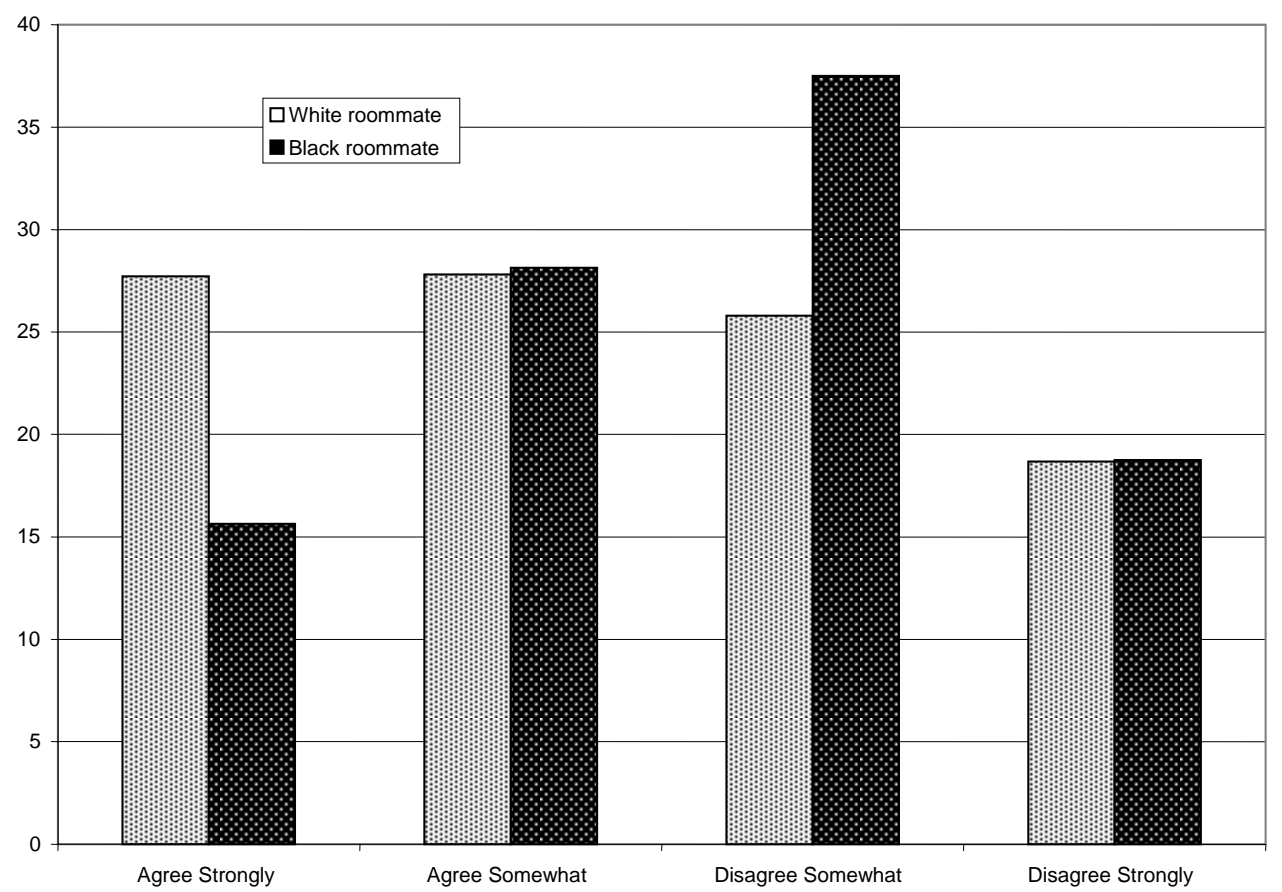


Response rate on CIRP survey for all entering students

\begin{tabular}{|c|c|c|c|c|}
\hline Total & 1997 & 1998 & 1999 & 2000 \\
\hline & $89 \%$ & $89 \%$ & $90 \%$ & $\mathrm{n} / \mathrm{a}$ \\
\hline 14,235 & 3,967 & 3,573 & 3,419 & 3,276 \\
\hline 3,246 & 1,014 & 920 & 633 & 679 \\
\hline 2,354 & 325 & 755 & 662 & 612 \\
\hline 5,583 & 1,449 & 1,166 & 1,615 & 1,353 \\
\hline 980 & 256 & 273 & 215 & 236 \\
\hline 63 & 21 & 5 & 12 & 25 \\
\hline 2,010 & 903 & 454 & 282 & 371 \\
\hline 47 & 19 & 8 & 8 & 12 \\
\hline 1,647 & 729 & 377 & 236 & 305 \\
\hline 61 & 26 & 14 & 7 & 14 \\
\hline 149 & 72 & 34 & 19 & 24 \\
\hline 106 & 57 & 21 & 12 & 16 \\
\hline 1,647 & 729 & 377 & 236 & 305 \\
\hline 369 & 133 & 91 & 75 & 70 \\
\hline $78 \%$ & $82 \%$ & $76 \%$ & $68 \%$ & $77 \%$ \\
\hline 1,278 & 596 & 286 & 161 & 235 \\
\hline
\end{tabular}

Final analysis sample

Of which: students opting to live in enrichment dormitories Of which: students requesting a specific roommate Of which: students failing to meet the lottery deadline Of which: students living alone during the first year Of which: students not assigned roommates

\section{Total number of students randomly assigned roommates}

Of which:

$$
\begin{array}{r}
\text { Students designated race as "black" only } \\
\text { Students designated race as "white" only } \\
\text { Students designated race as "Hispanic" (see text) } \\
\text { Students designated race as "Asian" (see text) } \\
\text { Students with other racial designations }
\end{array}
$$

\section{Target sample of white students opting for random assignment} Of which :

\section{Response rate on follow-up survey}

failed to respond to follow-up survey
1,278

596


Affirmative action in college admissions should be abolished (reversed) $^{\text {a }}$

Race discrimination is no longer a major problem in

America(reversed) ${ }^{a}$

Colleges should prohibit racist/sexist speech on campus ${ }^{b}$

Wealthy people should pay a larger share of taxes than they do now ${ }^{\mathrm{b}}$

Father's Education

Mother's Education

High School Grade Point Average

Test Scores (ACT Scale)

Family Income $<\$ 50,000$

Family income $\$ 50,000$ to $\$ 74,999$

Family income is $\$ 75,000$ to $\$ 149,999$

Family income $\$ 150,000$ to $\$ 199,999$

Family income $>\$ 200,000$

Missing Family Income

$\begin{array}{cccccc} & \text { White } & \text { White } & & \\ & \begin{array}{c}\text { respondents to } \\ \text { the follow-up } \\ \text { survey (all }\end{array} & \begin{array}{c}\text { respondents to } \\ \text { CIRP Entering }\end{array} & \begin{array}{c}\text { p value of } \\ \text { Survey but not }\end{array} & \text { t-test or Chi- roommates who t-test or Chi- } \\ & \text { assigned } & p \text { value of } \\ \text { All respondents } & \text { randomly- } & \text { randomly- } & \text { square test } & \text { FAlLED to square test } \\ \text { to the follow-up } & \text { assigned } & \text { assigned } & \text { comparing } & \text { respond to the comparing } \\ \text { survey } & \text { roommates) } & \text { roommates } & \text { (3) and (2) } & \text { follow-up survey } & \text { (5) and (2) }\end{array}$

survey

(2)

2.083
$(.813)$

3.215

(.719)

2.477

(.956)

2.524

(.927)

16.360

(1.980)

15.801

(2.083)

3.762
$(.260)$

$(.260)$
28.051

(2.616)

.114

.166

.405

.094
.121

.121

$\mathrm{n}=1,558$
(3)

(4)

.459

2.033
$(.774)$

(.772)

3.166

(.723)

2.434

$(.942)$

2.518

(.928)

16.362

(1.921)

15.810

(2.023)

3.775

$(.251)$
28.209

(2.594)

.105

.159

.417

.101

$\mathrm{n}=1,278$

3.172

(.730)

2.424

(.958)

2.489

(.929)

16.399

(1.977)

15.911

(1.978)

3.752
$(.280)$

28.372

(2.854)

.112

.150
.375

.375
.098
.167

.167

$\mathrm{n}=9,099$
(5)

(6)

.110

$.783-3.763$

(.733)

.725

2.504

.289

$(.952)$

(.860)

.519

.086

16.565

(1.831)

15.903

(1.946)

.006

.053

(.276)

27.888

(2.457)

.068

.000
.093

.211

.086

.001
Black

respondents to

$p$ value of CIRP Entering $p$ value of $t$ t-test or Chi- Survey but not test or Chi-

square test randomly- square test

$\begin{array}{lccc}\text { assigned } & \text { comparing } & \text { assigned } & \text { comparing } \\ \text { coommates } & (7) \text { and (2) } & \text { roommates } & \text { (9) and (7) }\end{array}$

$$
\begin{array}{llll}
(7) & (8) & \text { (9) }
\end{array}
$$

.020

.323

3.558

(.682)

2.617

(1.153)

2.620

(1.089)

15.834

(2.230)

15.957

(1.922)

3.543

(.366)

25.134

(2.952)

.170

.213
.000

.000

(.714)

3.650

(.615)

.196

.463

2.743

(.891)

.066

15.089

(2.334)

15.155

(2.185)

.000

3.480

(.423)

.000

24.118

(3.630)

.392

.547

Note: Blacks randomly assigned rommates may or may not have been respondents to the follow-up survey.

a : scale: (4) Disagree Strongly; (3) Disagree Somewhat; (2) Agree Somewhat; (1) Agree Strongly

${ }^{\mathrm{b}}$ : scale: (4) Agree Strongly; (3) Agree Somewhat; (2) Disagree Somewhat; (1) Disagree Strongly 
Table 3: Ordered Probit and OLS Regressions Coefficients, and Standard Errors for Roommate Predictors of Attitudes of White Students 2-6 Years After Entering College

\section{ROOMMATES' CHARACTERISTICS}

Any black roommate(s)

Any other minority roommate(s)

Only white roommate(s) [omitted group]

At least one roommate with family income < $\$ 50,000$

At least one roommate with family income between $\$ 50,000$ and $\$ 74,999$

At least one roommate with family income between $\$ 75,000$ and $\$ 149,999$ [omitted group] between $\$ 150,000$ and $\$ 199,999$

At least one roommate with family income > $\$ 200,000$

\section{TIME}

Years since sophomore year

R-squared/Pseudo- ${ }^{2}$

Number of observations
At least one roommate with family income

Affirmative action in colllege admissions
should be abolished (reverse coding)

Affirmative action is justified if it

\begin{tabular}{|c|c|c|c|c|c|c|c|c|}
\hline \multicolumn{2}{|c|}{$\begin{array}{c}\text { Ordered Probit } \\
\text { Regressions }\end{array}$} & \multirow{2}{*}{$\begin{array}{c}\begin{array}{c}\text { OLS } \\
\text { Regression }\end{array} \\
.366^{\star}\end{array}$} & \multicolumn{2}{|c|}{$\begin{array}{c}\text { Ordered Probit } \\
\text { Regressions }\end{array}$} & \multirow{2}{*}{$\begin{array}{c}\begin{array}{c}\text { OLS } \\
\text { Regression }\end{array} \\
.429^{\star \star}\end{array}$} & \multicolumn{2}{|c|}{ Ordered Probit Regression } & \multirow{2}{*}{$\begin{array}{c}\text { OLS } \\
\text { Regression } \\
.470^{\star \star \star}\end{array}$} \\
\hline $.497^{\star \star}$ & $.489 * \star$ & & $.493^{\star \star}$ & $.506^{\star \star}$ & & $.743^{\star \star \star}$ & 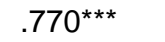 & \\
\hline$(.239)$ & $(.249)$ & $(.219)$ & $(.236)$ & $(.239)$ & $(.206)$ & $(.256)$ & $(.293)$ & $(.154)$ \\
\hline .027 & .029 & .032 & .096 & .154 & .120 & .022 & .056 & .025 \\
\hline$(.099)$ & $(.107)$ & $(.096)$ & $(.100)$ & $(.107)$ & $(.094)$ & $(.104)$ & $(.106)$ & $(.072)$ \\
\hline \multirow[t]{3}{*}{-} & - & - & - & - & - & - & - & - \\
\hline & $\begin{array}{l}.125 \\
(.129)\end{array}$ & $\begin{array}{l}.105 \\
(.113)\end{array}$ & & $\begin{array}{l}-.012 \\
(.131)\end{array}$ & $\begin{array}{l}-.006 \\
(.112)\end{array}$ & & $\begin{array}{l}.319 * \star \\
(.136)\end{array}$ & $\begin{array}{l}.180^{*} \\
(.087)\end{array}$ \\
\hline & $\begin{array}{c}.043 \\
(.108)\end{array}$ & $\begin{array}{c}.016 \\
(.096)\end{array}$ & & $\begin{array}{c}.055 \\
(.107)\end{array}$ & $\begin{array}{c}.032 \\
(.093)\end{array}$ & & $\begin{array}{c}.055 \\
(.112)\end{array}$ & $\begin{array}{c}.047 \\
(.075)\end{array}$ \\
\hline
\end{tabular}

Notes:

Standard errors are given in parentheses. Standard errors are adjusted for room clustering using Huber-White robust estimations.

All regressions include controls for respondent's: father's education, mother's education, family income, high school grade point average,

ACT/SAT score, CIRP-based attitudes about race discrimination, taxation of the rich and prohibition of racist/sexist speech;

for roommates': average father's education, average mother's education, average high school grade point average, average ACT/SAT score.

All regressions also control for respondent housing preferences, gender, cohort, test taken; values not shown.

"-" indicates that the variable was not included in the regression.

${ }^{a}$ Scale: 4) Disagree Strongly; 3) Disagree Somewhat; 2) Agree Somewhat; 1) Agree Strongly.

${ }^{b}$ Scale: 4) Agree Strongly; 3) Agree Somewhat; 2) Disagree Somewhat; 1) Disagree Strongly.

${ }^{*} \mathrm{p}<=.10$ ** $\mathrm{p}<=.05 * \star * \mathrm{p}<=.01$

Empathy or Antipathy - Tables AER Resubmission - Jan 2006.xls
Having a diverse student body is essential for high-quality education $b$ ensures a diverse student body on

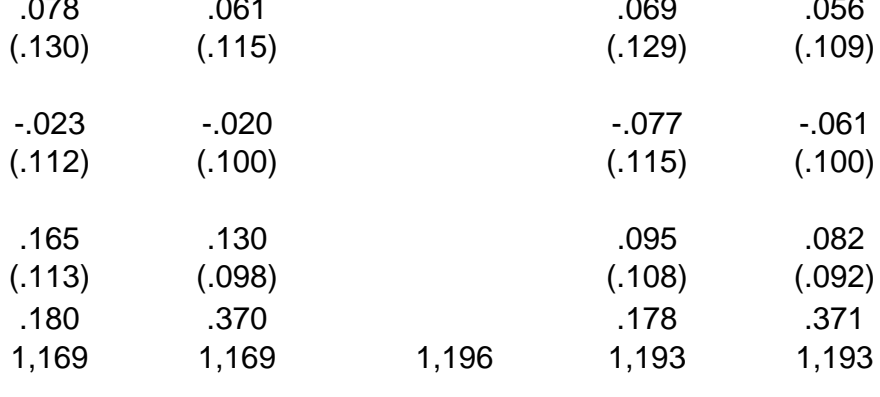


Table 4: OLS Regression Coefficients and Standard Errors for Roommate Predictors of Behaviors of White Students 2-6 Years After Entering College

\begin{tabular}{|c|c|c|c|c|}
\hline & $\begin{array}{l}\text { I have personal } \\
\text { contact with } \\
\text { people from other } \\
\text { racial/ethnic } \\
\text { groups } \\
\text { (Number of times } \\
\text { per month) } \\
\end{array}$ & $\begin{array}{l}\text { I interact } \\
\text { comfortably with } \\
\text { people from other } \\
\text { racial/ethnic } \\
\text { groups } \\
\text { (Number of times } \\
\text { per month) }\end{array}$ & $\begin{array}{c}\text { Fraction of } \\
\text { friends from own } \\
\text { racial/ethnic } \\
\text { background } \\
\end{array}$ & $\begin{array}{l}\text { Socialized with } \\
\text { someone with an } \\
\text { African-American } \\
\text { background } \\
\text { (Number of times } \\
\text { per month) } \\
\end{array}$ \\
\hline \multicolumn{5}{|l|}{ ROOMMATES' CHARACTERISTICS } \\
\hline Any black roommate(s) & $\begin{array}{l}2.949^{\star} \\
(1.730)\end{array}$ & $\begin{array}{l}2.844^{\star *} \\
(1.436)\end{array}$ & $\begin{array}{l}-.048 \\
(.045)\end{array}$ & $\begin{array}{c}1.830 \\
(1.826)\end{array}$ \\
\hline Any other minority roommate(s) & $\begin{array}{l}.052 \\
(.794)\end{array}$ & $\begin{array}{l}.214 \\
(.740)\end{array}$ & $\begin{array}{l}-.011 \\
(.016)\end{array}$ & $\begin{array}{l}-.982 \\
(.911)\end{array}$ \\
\hline Only white roommate(s) [omitted group] & - & - & - & - \\
\hline \multicolumn{5}{|l|}{ At least one roommate with family income $<$} \\
\hline$\$ 50,000$ & $\begin{array}{l}.719 \\
(.963)\end{array}$ & $\begin{array}{l}1.042 \\
(.895)\end{array}$ & $\begin{array}{l}.026 \\
(.019)\end{array}$ & $\begin{array}{l}2.306^{\star *} \\
(1.073)\end{array}$ \\
\hline \multicolumn{5}{|l|}{ At least one roommate with family income } \\
\hline between $\$ 50,000$ and $\$ 74,999$ & $\begin{array}{l}.996 \\
(.754)\end{array}$ & $\begin{array}{l}.267 \\
(.744)\end{array}$ & $\begin{array}{l}-.024 \\
(.018)\end{array}$ & $\begin{array}{c}1.7622^{*} \\
(.968)\end{array}$ \\
\hline $\begin{array}{l}\text { At least one roommate with family income } \\
\text { between } \$ 75,000 \text { and } \$ 149,999 \text { [omitted } \\
\text { group] }\end{array}$ & - & - & - & - \\
\hline $\begin{array}{l}\text { At least one roommate with family income } \\
\text { between } \$ 150,000 \text { and } \$ 199,999\end{array}$ & $\begin{array}{c}.851 \\
(.918)\end{array}$ & $\begin{array}{c}.883 \\
(.871)\end{array}$ & $\begin{array}{l}-.010 \\
(.019)\end{array}$ & $\begin{array}{c}1.382 \\
(1.127)\end{array}$ \\
\hline \multicolumn{5}{|l|}{ At least one roommate with family income > } \\
\hline$\$ 200,000$ & $\begin{array}{l}.592 \\
(.868)\end{array}$ & $\begin{array}{l}1.349^{*} \\
(.741)\end{array}$ & $\begin{array}{l}-.007 \\
(.019)\end{array}$ & $\begin{array}{c}1.064 \\
(1.026)\end{array}$ \\
\hline \multicolumn{5}{|l|}{ TIME } \\
\hline Years since sophomore year & $\begin{array}{l}-.743 \\
(.820)\end{array}$ & $\begin{array}{l}-.689 \\
(.802)\end{array}$ & $\begin{array}{l}.006 \\
(.015)\end{array}$ & $\begin{array}{l}-1.333 \\
(.918)\end{array}$ \\
\hline R-squared & .189 & .201 & .171 & .230 \\
\hline Number of observations & 1,257 & 1,254 & 1,245 & 1,243 \\
\hline \\
\hline \multicolumn{5}{|c|}{$\begin{array}{l}\text { Notes: } \\
\text { Standard errors are given in parentheses. Standard errors are adjusted for room clustering using Huber-White robust estimations. } \\
\text { All regressions include controls for respondent's: father's education, mother's education, family income, high school grade point average, } \\
\text { ACT/SAT score, CIRP-based attitudes about race discrimination, taxation of the rich and prohibition of racist/sexist speech; } \\
\text { for roommates': average father's education, average mother's education, average high school grade point average, average ACT/SAT score } \\
\text { All regressions also control for respondent housing preferences, gender, cohort, test taken; values not shown. } \\
\text { "“" indicates that the variable was not included in the regression. }\end{array}$} \\
\hline
\end{tabular}


White respondents to the follow-up survey

(all randomly

assigned roommates)

Dependent variables (all gathered in follow-up survey)

Mean Std. Dev.

Attitudes

Affirmative action in college admissions should be abolished (reverse coding) ${ }^{a}$

Having a diverse student body is essential for high-quality education ${ }^{\text {b }}$

Behaviors

I have personal contact with people from other racial/ethnic groups (number of times per month)

I interact comfortably with people from other racial/ethnic groups (number of times per month)

Fraction of friends from own racial/ethnic background

20.559

Socialized with someone with an African-American background (number of times

\section{Respondents (all gathered in entering student survey)}

\begin{tabular}{|c|c|c|}
\hline Affirmative action in college admissions should be abolished (reverse coding) ${ }^{a}$ & 2.016 & $(.772)$ \\
\hline Racial discrimination is no longer a major problem in America (reverse coding) ${ }^{a}$ & 3.166 & $(.723)$ \\
\hline Colleges should prohibit racist/sexist speech on campus ${ }^{b}$ & 2.434 & $(.942)$ \\
\hline Wealthy people should pay a larger part of taxes than they do now ${ }^{b}$ & 2.518 & $(.928)$ \\
\hline Father's Education & 16.362 & $(1.920)$ \\
\hline Mother's Education & 15.810 & (2.023) \\
\hline High School grade point average & 3.775 & $(.251)$ \\
\hline Test Scores (ACT scale) & 28.209 & (2.594) \\
\hline Family Income $<\$ 50,000$ & .105 & $(.306)$ \\
\hline Family income $\$ 50,000$ to $\$ 74,999$ & .159 & $(.366)$ \\
\hline Family income is $\$ 75,000$ to $\$ 149,999$ & .417 & $(.493)$ \\
\hline Family income $\$ 150,000$ to $\$ 199,999$ & .101 & $(.301)$ \\
\hline Family income $>\$ 200,000$ & .119 & $(.324)$ \\
\hline
\end{tabular}

Roommates (all gathered in entering student survey)

Any black roommate(s)

Any other minority roommate(s)

Fathers' Education

Mothers' Education

$15.809 \quad(1.963)$

High School grade point average

$(.268)$

Test Scores (ACT scale)

At least one roommate with family income $<\$ 50,000$

At least one roommate with family income between $\$ 75,000$ and $\$ 149,999$

At least one roommate with family income $>\$ 200,000$

Notes:

a : scale: (4) Disagree Strongly; (3) Disagree Somewhat; (2) Agree Somewhat; (1) Agree Strongly

${ }^{\mathrm{b}}$ : scale: (4) Agree Strongly; (3) Agree Somewhat; (2) Disagree Somewhat; (1) Disagree Strongly

${ }^{\mathrm{c}}$ : averaged over all roommates for a given respondent 